doi: 10.12957/childphilo.2019.37912

\title{
um menino no mundo
}

\author{
dagmar de mello e silva ${ }^{1}$ \\ universidade federal fluminense, brasil \\ orcid id: https:/ / orcid.org/0000-0002-5863-3607 \\ larissa brito dos reis príncipe ${ }^{2}$ \\ universidade federal fluminense, brasil \\ orcid id: https://orcid.org/0000-0002-7599-2273
}

resumo

O presente trabalho é fruto de encontros com o Cinema, na Disciplina de Atividades Culturais, componente curricular do curso de formação de professores da Faculdade de Educação da Universidade Federal Fluminense. O objetivo consistiu em produzir Experiências Estéticas com as imagens-movimento da linguagem cinematográfica, para além das usuais formas didatizantes e utilitaristas de exemplificar conteúdos disciplinares. Apostamos na potência das imagens-movimento se constituírem Imagensafecção, dispositivo estético acionador de relações entre pensamento e linguagem, de modo a contribuir para uma pausa no tempo, possibilitando tempo para olharmos, com mais cuidado, as condições existenciais históricamente constituídas no mundo contemporâneo. Enfim, foi através do cinema como dispositivo sócio analítico e recurso metodológico na formação de estudantes de graduação em licenciaturas, que resultou esse artigo. A produção escolhida é um longa metragem de animação cuja história se desvela sob o olhar de uma criança diante da descoberta de um mundo contaminado pelas adversidades produzidas pelo contexto capitalista. Como suporte teórico nos debruçamos em autores que analisam o modelo político e socioeconômico capitalista e seus efeitos sobre a condição humana. Através de $O$ Menino e o mundo, aluna e professora, procuram travar conversações a respeito de suas diferentes, mas por isso mesmo potentes, concepções acerca do campo educacional, do mundo do trabalho, do consumismo e da alienação decorrente dos atuais modos de produção. Vale enfatizar que o artigo em si, é resultante da abordagem metodológica da disciplina.

palavras-chave: cinema; sociedade; cultura; infância.

abstract

\section{one boy in the world}

This paper is the result of encounters with cinema in a course entitled Cultural Activities, a required class in the undergraduate education program of the School of Education at Brazil's Fluminense Federal University. The goal was to produce aesthetic experiences with the moving images of cinematic language that would go beyond the usual didactic and utilitarian ways of exemplifying course content. We counted on the power of moving images to produce affective images, an aesthetic device that drives the relation between thought and language, thereby contributing to a pause in time, thereby allowing us the opportunity to examine more carefully the existential human condition as historically constituted in the world today. This paper was thus the result of using cinema as a tool of social analysis and a methodological resource for the training of undergraduate education students. The cinematic artifact presented here is an animated feature whose story unfolds through the eyes of a child confronting a world tainted by the misfortunes of

\footnotetext{
${ }^{1}$ E-mail: dag.mello.silva@gmail.com

2 E-mail: larissa_principe@hotmail.com 
capitalism. For theoretical support, we focus on authors who analyze the capitalist political and socioeconomic model and its effects on the human condition. Through $O$ menino e o mundo, a student and teacher share their different, but nonetheless powerful, ideas about the field of education, work, and the consumerism and alienation that result from current modes of production. It is particularly important to emphasize that the paper itself is a byproduct of the methodological approach of the course.

keywords: cinema; society; culture; childhood.

resumen

\section{un niño en el mundo}

El presente trabajo es fruto de encuentros con el Cine, en la Disciplina de Actividades Culturales, componente curricular del curso de formación de profesores de la Facultad de Educación de la Universidad Federal Fluminense. El objetivo consistió en producir Experiencias Estéticas con las imágenes-movimiento del lenguaje cinematográfico, además de las usuales formas didatizantes y utilitaristas de ejemplificar contenidos disciplinares. Apostamos en la potencia de las imágenes-movimiento si constituyen imágenes-afección, dispositivo estético accionador de relaciones entre pensamiento y lenguaje, para contribuir a una pausa en el tiempo, posibilitando tiempo para mirar con más cuidado las condiciones existenciales históricamente constituidas en el mundo contemporáneo .En fin, fue a través del cine como dispositivo socio analítico y recurso metodológico en la formación de estudiantes de graduación en licenciaturas, que resultó ese artículo. La producción escogida es un largometraje de animación cuya historia se desvela bajo la mirada de un niño ante el descubrimiento de un mundo contaminado por las adversidades producidas por el contexto capitalista. Como soporte teórico nos inclinamos en autores que analizan el modelo político y socioeconómico capitalista y sus efectos sobre la condición humana. A través de El Niño y el mundo, alumna y profesora, procura frenar conversaciones acerca de sus diferentes concepciones, pero potentes acerca del campo educativo, del mundo del trabajo, del consumismo y de la alienación derivada de los actuales modos de producción. Es importante enfatizar que el artículo en sí, es el resultado del enfoque metodológico de la disciplina.

palabras clave: cine; sociedade; cultura; infancia. 
um menino no mundo

um início de conversa...

Certas conversações duram tanto tempo, que não sabemos mais se ainda fazem parte da guerra ou já da paz. É verdade que a filosofia é inseparável de uma cólera contra a época, mas também de uma serenidade que ela nos assegura. Contudo, a filosofia não é uma Potência. As religiões, os Estados, o capitalismo, a ciência, o direito, a opinião, a televisão são potências, mas não a filosofia. A filosofia pode ter grandes batalhas interiores (idealismo - realismo, etc.), mas são batalhas risíveis. Não sendo uma potência, a filosofia não pode empreender uma batalha contra as potências; em compensação, trava contra elas uma guerra sem batalha, uma guerra de guerrilha. Não pode falar com elas, nada tem a lhes dizer, nada a comunicar, e apenas mantém conversações. Como as potências não se contentam em ser exteriores, mas também passam por cada um de nós, é cada um de nós que, graças à filosofia, encontra-se incessantemente em conversações e em guerrilha consigo mesmo (

Gilles Deleuze (Conversações, 1992)

de onde surgem essas conversações?

Este artigo é expressão de "certas conversações" que possibilitaram a uma aluna e sua professora travarem batalhas que as colocaram em "incessantes guerrilhas" frente a questões que permeiam a educação e a infância. Conversações que surgiram da diferença de pensamentos entre uma e outra, mas que, justamente por se afirmarem na diferença que nos é imanente, produziram deslocamentos, potencializando esse encontro que só foi possível a partir da disciplina Conversações Transversais com o Cinema, elaborada para atender ao Componente Curricular Atividades Culturais, do curso de Formação de Professores da Faculdade de Educação da Universidade Federal Fluminense.

Há que se destacar que esse componente curricular passou a fazer parte das disciplinas obrigatórias do currículo da $\mathrm{FEUFF}^{3}$ a partir do ano de 1993, com a finalidade de oferecer aos futuros professores uma formação mais estética, que

\footnotetext{
${ }^{3}$ Faculdade de Educação da Universidade Federal Fluminense
} 
um menino no mundo

pudesse ampliar o olhar dos estudantes das licenciaturas para além das concepções focadas nos pragmatismos instrumentais que muitas vezes permeiam e territorializam a formação de professores em um campo de fronteiras minadas, implodindo as relações de sentido que potencializam suas escolhas iniciais pela docência.

A disciplina, também, foi pensada a partir de princípios epistemológicos construídos ao longo de pesquisas da professora que ministrou o curso. Princípios esses que compreendem que a formação acadêmica não se restringe aos ditames de um conhecimento que se pauta unicamente na racionalidade lógica formal. Para além dessa racionalidade instrumental, a professora compreende que existem outras formas de pensar que promovem enunciados para a vida e ultrapassam as margens dessa racionalidade que, ao longo da história do conhecimento ocidental, procurou atender às significações objetivas dominantes como "uma terrível forma de julgar em nome de deus" (DELEUZE, 1997). Assumindo um caminho contrário a esta perspectiva moral do pensamento, a professora encontrou no cinema, uma proposta política que se constituiu como dispositivo para acionar um pensamento problematizador de questões que muitas vezes permanecem, cristalizadas por uma racionalidade que institui modos apropriados para a produção do conhecimento.

A professora entende que nenhum conhecimento está dado ou se reduz à mera representação das coisas do mundo. Por concordar com Deleuze (2006) ela considera que o pensamento não é natural, não se pensa de boa vontade. É necessário que algo force o pensar. Foi a partir dessa ideia que a professora elaborou a disciplina, como espaço e tempo de encontro de corpos com um cinema que forçasse o pensar, produzindo intensidades e efeitos.

Foi, também, por isso, que a professora se ocupou em criar uma atmosfera na qual o cinema não se reduzisse às imagens-movimento que remetem a uma imagem ortodoxa do pensamento. Ela queria que o cinema promovesse acontecimentos por imagens-tempo que acionassem o pensamento de seus alunos e alunas, levando-os a problematizarem supostas naturalizações da vida cotidiana, produzindo um pensar descentrado e politicamente potente. Ela desejava que o 
cinema pudesse dar lugar a um tempo intensivo e intempestivo em novos acontecimentos.

O desejo da professora produziu efeitos e as imagens-movimento do cinema ao se despojarem do domínio da mera imagem cinematográfica, passaram a habitar o tempo por insubordinação. Tempo e movimento criaram novas relações entre pensamento e cinema, produzindo intensidades. As imagensafecção atuaram como dispositivos estéticos, privilegiando experiências convidativas para pensarmos o mundo através de múltiplas visões. Visões que não se reduzem à arbitrariedade dos signos abrigados em significados prédeterminados ou do olhar "naturalizado" das representações. Ao longo da disciplina, alunos/as e professora experimentaram o cinema a partir da diferença e da multiplicidade do pensamento. Colocaram-se numa condição de vulnerabilidade diante do que viam na tela. Se permitiram deixarem-se levar pelas inquietações provocadas pelas imagens, desvirtuando a imagem das amarras de perspectivas miméticas ou realistas. Para isso foi preciso despirem-se de regras pré-estabelecidas ou de temas a "serem debatidos" e se dispuseram a assistirem aos filmes como campo de experimentação do pensamento.

Ao longo desse processo constatamos a necessidade de romper com uma percepção óptica que captura a imagem com o olhar. É preciso conceber as sequencias das imagens em movimento por "um corte móvel de um Todo que muda, isto é, de uma duração, de um devir universal" (DELEUZE, 1983, p. 92), o cinema presenciado por uma variação de cortes que provocam deslocamentos, profusões perceptivas que fazem ver os mínimos instantes por onde tudo se move, tudo reage, operando análises muito mais sensíveis do que inteligíveis, produzindo "um desejo de recomeçar a história do mundo a partir da história do cinema". (DELEUZE, 1983).

Essa visão só foi possível porque, tal como Trindade a professora entendia que:

A comunicação não é a busca pela verdade, muito menos o desvelar do ser. Não nos comunicamos para achar algo em comum, não queremos o que há de igual. Comunicar-se é, para nós, criar afetos. Estamos a anos luz de distância do medíocre, do médio, da medida. A linguagem é nossa chance de criar afetos, 
conceitos, funções, linhas de fuga. Sem a linguagem teríamos um caminho a menos para fazer passar fluxos. Que façamos da língua um canto, uma melodia, um devir. (TRINDADE, 2014, p. 03)

Conceitualmente, para a professora, arte - e aqui inclui-se o cinema como arte - não só é expressão de linguagem, mas experiência do pensamento que abre a condição humana para uma comunicação estética em que a linguagem formal nem sempre é capaz de captar - arte/pensamento. Foi na tentativa de dar corpo a essa perspectiva teórica que ao longo da disciplina, professora e alunos, assistiram diversos filmes cujos critérios de escolha fluíram pelos desejos e memórias de todos e todas.

Como participantes desse processo a aluna e a professora - partindo dos depoimentos dos demais espectadores/alunos e alunas que realizaram suas análises a respeito de suas participações no curso - concluíram que o mesmo, promoveu espaços/tempos de experiências formativas, que extrapolaram os conteúdos disciplinares e ampliaram olhares e escutas, desencadeando considerações para além dos discursos que naturalizam funções determinadas para a educação, possibilitando "explodir o universo carcerário" dos determinismos que produzem um modo banalizado do pensamento sobre a educação, "permitindo-nos empreender viagens aventurosas entre as ruínas" dessas naturalizações "arremessadas a distância” (BENJAMIN, 1985, p.189)

Apoiadas nesses depoimentos, aluna e professora escreveram esse artigo que consistiu numa tentativa de dar forma à estética como o cinema foi experimentado no contexto da disciplina, onde professora e alunos/alunas em processo de formação, com diferentes concepções teóricas, puderam experenciar estranhamentos que possibilitaram novos pensares a respeito da importância do cinema na Educação.

Foi nessa dimensão, de resistência do olhar que estranha descortinando novos mundos, que a disciplina foi vivida. Na perspectiva de atuar, ou seja, no exercício educativo do olhar. Um olhar que "é ao mesmo tempo, sair de si e trazer o mundo para dentro de si" como afirma Chauí (1998).

Ao propor um exercício educativo do olhar, professora e aluna estão se referindo a possibilidade da se construir espaços e tempos para uma experiência 
estética que contribua para uma pausa no tempo, que nos dê tempo para olhar, com mais cuidado, nossas condições existenciais historicamente constituídas. Enfim, o cinema, sob essa perspectiva, atuaria como dispositivo sócio analítico para um "olhar atento". Olhar de estranhamento, a contrapelo das banalizações e naturalizações de práticas sociais que históricamente se instituiram em nossos cotidianos, justificadas por práticas discursivas que impõem modos únicos de ver e saber. Nesse sentido, o Cinema pode oferecer uma condição de "olhar estrangeiro" que segundo Peixoto (1990, p. 363):

É capaz de ver aquilo que os que lá estão não podem mais perceber (...). Ele é capaz de olhar as coisas como se fosse pela primeira vez e de viver histórias originais (...). Contar histórias simples, respeitando os detalhes, deixando as coisas aparecerem como são.

Essa condição do olhar pode ser reveladora de tempos e espaços de vida, histórias, enfim, estéticas existenciais, muitas vezes adormecidas nos olhares de práticas pedagógicas que naturalizam as realidades adversas vividas por muitos educandos. Experiências que nos fazem crer em um sujeito sem contornos definidos, considerando os lugares de onde seus discursos são enunciados, as espacialidades por onde circulam, para quem são remetidos e como são recebidos. Forma de recepção que nos ajuda a pensar sobre o significado das diversas dimensões do ato educativo como um desafio para a criação de práticas educacionais nas quais os sujeitos sejam autores do seu livre pensar e fazer. Além da possibilidade de explodirmos, tal qual sugere Walter Benjamin (1985), com o universo de uma epistemologia que encarcera disciplinas em mundos próprios, apartados daquilo que se vivencia sensívelmente.

Muitas são as perspectivas que são produzidas em torno de uma discussão que foi central para a disciplina, ou seja; "a educação do olhar". Sabe-se que atualmente muitos pesquisadores/as brasileiros/as tem se ocupado da tarefa de pensar essa discussão de forma complexa e por vias teóricas distintas a partir de análises que problematizam a relação entre cinema e educação, de modo a criar uma pedagogia preocupada com a recepção da linguagem audiovisual e a formação do olhar pelas vias da experiência; em contraposição ao que vem sendo praticado em boa parte das instituições escolares brasileiras, onde, muitas vezes, 
um menino no mundo

essas práticas reduzem essa relação a uma mera justaposição do cinema na educação, tornando-o instrumento didático que contribua para a aprendizagem dos conteúdos curriculares ou, numa outra versão, mas não menos instrumental, como veículo de reflexão necessária, sobre uma dada realidade, com a finalidade de se atingir uma consciência crítica das coisas que já estão postas no mundo.

De certo nenhuma dessas duas opções agradava a professora. Para a professora interessava muito mais as possibilidades presentes nas intersecções entre o cinema e a educação, para que pudessem produzir novas visualidades do mundo. O que ela se propôs como desafio foi promover um deslocamento "do poder" do olhar para um olhar que pode, enxergar e reparar a vida em sua potência. Mais do que um olhar que ilumina, que conhece e esclarece, foi de uma experiência sensível com o olhar que a disciplina procurou tratar. E foi nesse exercício de buscar uma estética, através do cinema, que pudesse se concretizar, não numa proposição educativa, mas sim, numa ética do olhar, que a professora parafraseou a pergunta que Deleuze faz sobre obra de Espinoza:

O que pode o cinema em conversação com a educação?

pontos de partida para "certas conversações" entre aluna e professora

Era só mais um menino entre tantos que vivem por aí, nos confins de recôncavos áridos de nosso país. Não fosse a miséria e a fome, era só mais um menino o que ele mais queria ser. Apenas um menino e, que por ser um menino, se permitia sonhar, com um mundo que explode em cores ao seu olhar, mesmo diante das adversidades em preto e branco, que seu corpo miúdo e frágil, tinha que enfrentar...

(Composição coletiva entre aluna e professora)

A animação brasileira de Alê Abreu, consegue transitar poeticamente, pela condição de desigualdade social e extrema pobreza de nosso povo, sob o olhar de um menino. Um infante...

Talvez por isso o filme transite por uma língua que não nomeia, pois, como nomear uma vida tão ferina frente a uma infância que resiste insistindo em 
enxergar o mundo de modo tão potente e inaugural?

Quem sabe essa não tenha sido uma opção intencional do cineasta? Optar pelos olhos e pela língua sem palavras pré-formadas da infância, para retratar, através de um jogo de cores que cintilam diante do olhar de resistência de um menino que ainda vê poesia na dureza de condições sócio históricas que estão recorrentemente a lhe dizer não, sob nuances de cores esmaecidas que desbotam em paisagens despojadas dos direitos básicos da vida. E mesmo diante dessa realidade o Menino diz sim. Pois não é que "as crianças estão sempre a inventar"... (MARTON; SILVA, 2014, p.269)

[...] novas formas de apropriação das imagens e experiências daquilo que vivenciam. Talvez possamos afirmar que o modo como exercem o pensamento pode nos ensinar a pensar o mundo de forma menos fragmentada, como uma tessitura que, tal qual Sherazad, reinventa a vida em narrativas. Através de histórias abertas, as crianças rompem com a temporalidade homogênea e vazia das metanarrativas iluminadas pelo projeto de uma Modernidade que prometeu ao homem a felicidade através da emancipação de seus dogmas e mitos. Elas nos recordam que o mundo imaginário é fonte inesgotável de sonhos. (MARTON; SILVA, 2014, p.269)

É através do Menino da história, dessa força imanente da infância, que o filme conduz aluna e professora ao encontro com o outro. Menino sem palavras que enxerga o mundo por luzes e cores que reinventam, a todo custo, esperanças de outras formas e mobilidades para a condição humana...

Acreditar no mundo é o que mais nos falta; nós perdemos completamente o mundo, nos desapossaram dele. Acreditar no mundo significa principalmente suscitar acontecimentos, mesmo pequenos, que escapem ao controle, ou engendrar novos espaçostempos, mesmo de superfície ou volumes reduzidos. (DELEUZE, 1992, p. 18).

O filme tem início numa explosão de cores vivas, quem sabe (?) como prenuncio para dizer pelos olhos do Menino, que apesar de tudo, ainda nos resta a esperança de acreditar no mundo, mesmo quando tentam nos desapossar dele? A obra assume, juntamente com o seu personagem principal, o compromisso de nos dar a ver a vida em toda a sua crueza, mas, sua maior transgressão está no fato de mostrar que nada está dado, pois, é através de sua poesia afásica que a obra responde à barbárie de modo encantador, trazendo para a animação os sentidos, no lugar das palavras ajustadas em seus significados pré-determinados.

childhood $\mathcal{E}$ philosophy, rio de janeiro, v. 15, abr. 2018, pp. 01- 19 issn 1984-5987 
Menino que surge de formações caleidoscópicas, trazendo consigo a alegria intensa de estar em contato com a natureza, junto aos seus pais, mesmo nas adversidades geopolíticas do contexto que habita. Entretanto, por conta do solo seco e improdutivo, seu pai necessita partir para a cidade grande em busca de melhores condições de sustento para a família. Com sua partida o pai leva junto a alegria do menino que passa a esperar.... Uma espera que nunca chega.

Um dia o menino cansa da espera.... Faz sua trouxinha e dá início a sua jornada, rumo à Grande Cidade. Parte em busca da figura paterna, mas no caminho, descobre em si um mundo em devir, um mundo que não se reduz a existência a uma interioridade, posto que abre o ser para o que está no mundo, na relação com a exterioridade das coisas.

Alê de Abreu, cria imagens em movimento que ultrapassam o mero deslocamento de corpos. Imagens-afecção, que deslocam nossas almas do apaziguamento da mesmice. Tudo é muito original. Desde a simplicidade dos traços à edição de imagens sobrepostas em movimentos dinâmicos que dão à obra um ar psicodélico, quando em conjunto com a trilha sonora, misturam os sentidos da escuta e da visão.

Nesse processo de efervescência de sentidos, aquilo que ainda não conhecemos não se revela por exegeses que buscam a verdade, mas nos surpreendem ao se presentificarem naquilo que nos liga ao humano sem a necessidade das palavras para nos contar. (MARTON; SILVA, 2014, pp. 272 - 273)

Foi assim que as imagens de Menino e o mundo arrebataram aluna e professora, levando-as a sentir, através da experiência fílmica, as forças do mundo, colocando o pensamento em movimento, forçando-as a pensar em outras possibilidades de resistência posto que: "Sem algo que force a pensar, sem algo que violente o pensamento, este nada significa. Mais importante do que o pensamento é o que 'dá a pensar'” (DELEUZE, 2003, p. 89). 
Menino, mundo, mundo, menino (...)

Selva de pedra, menino microscópico

O peito gela onde o bem é utópico

É o novo tópico, meu bem

A vida nos trópicos

Não tá fácil pra ninguém

É o mundo nas costas e a dor nas custas

Trilhas opostas, la plata ofusca

Fumaça, buzinas e a busca

Faíscas na fogueira bem de rua, chamusca

Sono tipo slow blow, onde vou, vou

Leio vou, vô, e até esqueço quem sou, sou

Calçada, barracos e o bonde

A voz ecoa sós mas ninguém responde

Miséria soa como pilhéria

Pra quem tem a barriga cheia, piada séria

Fadiga pra nóis, pra eles férias

Morre a esperança

E tudo isso aos olhos de uma criança

Menino, mundo, mundo, menino (...)

(Emicida)

O olhar da aluna sobre o filme, enxerga o pensamento marxista a respeito da formação do homem, omnilateral4. Formação esta que tornaria o ser humano capaz de produzir e fruir ciência, arte e técnica. O indivíduo, entretanto, diante de uma sociedade capitalista, por tantas vezes se encontra no papel de vítima do trabalho alienado, sem consciência de sua importância social, distante de uma condição política de emancipada.

A alienação humana, e acima de tudo a relação do homem consigo próprio, é pela primeira vez concretizada e manifestada na relação entre cada homem e os demais homens. Assim, na relação do trabalho alienado cada homem encara os demais de acordo com os padrões e relações em que ele se encontra situado como trabalhador. (MARX, Primeiro Manuscrito, 2017, p. 06)

Marx cria, conceitualmente novos significados para a palavra alienação, atribuindo-lhe um sentindo que relaciona o trabalho à condição humana e tece suas críticas frente aos modos de produção capitalista, ou seja, o fato do trabalhador ser ou não alienado depende da sua consciência. O operário alienado

\footnotetext{
${ }^{4} \mathrm{O}$ conceito de omnilateralidade é de grande importância para a reflexão em torno do problema da educação em Marx. Ele se refere a uma formação humana oposta à formação unilateral provocada pelo trabalho alienado, pela divisão social do trabalho, pela reificação e pelas relações de exploração burguesas.
}

childhood E philosophy, rio de janeiro, v. 15, abr. 2018, pp. 01- 19 issn 1984-5987 
é aquele que não possui controle sobre as etapas que envolvem todo o processo de produção no trabalho, processo esse que, com as mudanças nos modos de produção desde a Modernidade até os dias atuais, passou a ser fragmentado e controlado pelos donos dos meios de produção.

Para Marx o trabalho é mais uma forma, senão, talvez, a mais importante e primordial, do ser humano se sentir realizado, podendo desenvolver suas aptidões mentais e físicas:

A construção prática de um mundo objetivo, a manipulação da natureza inorgânica, é a confirmação do homem como um enteespécie, consciente, isto é, um ser que trata a espécie como seu próprio ser ou a si mesmo como um ser-espécie. Sem dúvida, os animais também produzem. Eles constroem ninhos e habitações, como no caso das abelhas, castores, formigas, etc., porém, só produzem o estritamente indispensável a si mesmos ou aos filhotes. Só produzem em uma única direção, enquanto o homem. Produz universalmente. Só produzem sob a compulsão de necessidade física direta, ao passo que o homem produz quando livre de necessidade física e só produz, na verdade, quando livre dessa necessidade. Os animais só produzem a si mesmos, enquanto o homem reproduz toda a natureza. Os frutos da produção animal pertencem diretamente a seus corpos físicos, ao passo que o homem é livre ante seu produto. Os animais só constroem de acordo com os padrões e necessidades da espécie a que pertencem, enquanto o homem sabe produzir de acordo com os padrões de todas as espécies e como aplicar o padrão adequado ao objeto. Assim, o homem constrói também em conformidade com as leis do belo. (MARX, Primeiro Manuscrito, 2017, p. 07)

O trabalho alienado seria, então, a banalização da relação humana com o trabalho. Sendo, portanto, um afazer forçado, apenas utilizado como meio para satisfazer necessidades de um consumo mercantilista por meio do salário. Com as mudanças nos modos de produção capitalista, a relação ontológica entre homem e trabalho vem cada vez mais desapossando as pessoas do sentido atribuído a este por Marx.

Nessa relação o operário explorado executa o trabalho, mas o produto de seu esforço, ou seja, a mercadoria, é apropriada por quem detém a produção. $\mathrm{O}$ lucro não fica para o trabalhador, mas para quem controla o trabalho. Em suma, esse processo se torna um ciclo de produção e venda de um produto no qual, quem produziu, não poderá consumir, portanto, será um objeto alheio para quem o criou devido ao distanciamento entre o que foi produzido e sua forma final. 
Certamente o trabalho produz maravilhas para os ricos, mas produz privação para o trabalhador. Produz palácios, mas choupanas para o trabalhador. Produz beleza, mas enfermidade para o trabalhador. Substitui o trabalho por máquinas, mas atira uma parte dos trabalhadores num trabalho bárbaro e transforma outra parte em máquinas. Produz espírito, mas, para o trabalhador, produz a bestialização, o cretinismo. (MARX, 1996, p.111).

Trata-se do estranhamento do homem com relação a si mesmo como pertencente a um gênero, assim, como acontece com o estranhamento de sua existência (natureza) exterior e o estranhamento de sua existência espiritual. (RANIERI, 2001, p. 14).

Retomando a história do Menino, a aluna constrói sua análise, através das imagens que o filme lhe deu a pensar, diante das relações degradantes entre homem e trabalho na sociedade capitalista contemporânea.

O menino que, até então, vivia em uma casinha isolada, nos confins do nosso sertão, contemplava a vida de forma potente. Apesar da escassez material e da aridez do solo, as paisagens naturais insurgiam em cores através de seus grandes olhos e do som da flauta de seu pai quando este ainda se encontrava em seu convívio. Entretanto, com sua entrada na Grande Cidade, em busca do pai desaparecido, diante de uma multidão sem rosto, ele se choca ao se deparar com os gigantescos prédios urbanos e a correria da vida nesses grandes centros. Seu olhar assume uma nova estética, o mundo que antes lhe parecia um caleidoscópio de cores vibrantes, agora se apresenta em uma versão sofrida de tons esmaecidos, onde prevalecem as colorações de cinza e preto.

O filme utiliza cores e sons para mostrar o choque entre a vida na cidade grande e a vida no meio rural. A vida no campo é exposta através de múltiplas cores vivas e divertidas, que ressaltam frente a simplicidade dos pequenos acontecimentos cotidianos, mas, que estão prenhes de nascimentos, em toda a sua força motriz. Já a vida urbana é enfatizada por uma trilha sonora ruidosa e as imagens foram trabalhadas em uma paleta carregada de tons escuros.

Uma cena que chama a atenção da aluna e parece metaforizar as desigualdades entre classes, foi o confronto entre dois pássaros: um de penas longas e coloridas e outro, negro, que se assemelhava a uma ave de rapina. Para a aluna diante dessa cena, seria inevitável não nos remetermos à obra; "o Corvo, de Edgar Allan Poe, ave que se tornou símbolo da prenunciação de fatalidades. childhood E philosophy, rio de janeiro, v. 15, abr. 2018, pp. 01- 19 issn 1984-5987 
Mensageira de perdas irreparáveis através de sentenças de sofrimento, proferidas, pelo pássaro de mau agouro, sob uma espécie de ecolalia: "Nevermor".

"Nunca mais", "Nevermor", "Nunca mais"... Expressão repetida pelo pássaro agourento, que sentencia uma espécie de inevitabilidade frente a um sistema que nos desapossa de sentidos com a vida. A cena, também, reportou a aluna a uma analogia da árdua batalha entre os opostos. O dominado e o poder do dominante - que até hoje constitui a lógica de mercado capitalista.

O ser estranho a quem pertencem o trabalho e o produto deste, a quem o trabalho é devotado, e para cuja fruição se destina o produto do trabalho, só pode ser o próprio homem. Se o produto do trabalho não pertence ao trabalhador, mas o enfrenta como uma força estranha, isso só pode acontecer porque pertence a um outro homem que não o trabalhador. Se sua atividade é para ele um tormento, ela deve ser uma fonte de satisfação e prazer para outro. Não os deuses nem a natureza, mas só o próprio homem pode ser essa força estranha acima dos homens. (MARX, Primeiro Manuscrito, 2017, p. 07)

Outra cena se destaca: o menino, como metáfora profética de seu futuro na metrópole, surge sob a forma de um corpo adulto chegando em casa esgotado, após um dia inteiro de trabalho. Junto a ele está seu corpo/criança, a TV está ligada e os dois sentam em frente ao aparelho. Os conteúdos transmitidos são propagandas e anúncios que os deixam paralisados com suas luzes hipnóticas. Assim como uma metáfora do consumidor moderno frente ao fetiche das mercadorias5.

Numa mudança de cena, o pai do menino volta da sua viagem. A locomotiva para, e o menino percebe que todos os passageiros são iguais ao seu pai; uma repetição do mesmo. Não havia mais singularidades naquelas expressões humanas. A vida cotidiana dos grandes centros urbanos transformou aqueles homens em organismos autômatos.

A aluna, inspirada pelas imagens do filme e através de suas conversações com a professora, conclui que nas sociedades capitalistas, as pessoas apresentam em seus corpos, em suas mentes, nos seus jeitos de ver o mundo, enfim, em seus modos de viver; as marcas das profissões que exercem e da classe social da qual

\footnotetext{
${ }^{5} \mathrm{O}$ fetichismo da mercadoria opera transformações subjetivas, ou seja, abstrações de valor econômico, nos quais as pessoas acreditam que determinadas coisas materiais têm um valor intrínseco
} 
fazem parte, como se o ser humano fosse sendo moldado pelo trabalho.

Ela comente que se lembra de ter lido em Frigotto (2005) que o ser humano ao transformar a natureza pelo trabalho, não só transforma a si mesmo, mas também a atividade prática que é a fonte do conhecimento, da cultura e da conscientização. E pergunta para a professora: Será que o capitalismo inverteu esse processo?

a vez da professora pensar.

Menino, mundo, mundo, menino Gente, carro, vento, arma, roupa, poste Aos olhos de uma criança Quente, barro, tempo, carma, roupa, nóis

Aos olhos de uma criança ... Airgela adiv aigrene açrof Roma zap edadrebil zov edatnov Menino, mundo, mundo, menino

(Emicida)

Como entender as relações de poder e dominação capitalista em nosso tempo? A professora prefere caminhar sobre questões relativas aos processos de subjetivação. Pensar nas práticas e mecanismos de produção de subjetividade no mundo contemporâneo. Produções que nos desapossam de uma "condição menino" para nos tornar "pais autômatos" de uma viagem cujo o retorno não produz diferença, muito pelo contrário, confere banalização do mesmo e mediocridade à nossa condição existencial.

Estamos diante de forças cognitivas, econômicas, organizacionais, sociais, políticas e até mesmo afetivas que nos empurram numa direção em que os desvios e as linhas de fuga ficam cada vez mais difíceis de serem acessados. Como lidar com os efeitos de uma biopolítica, forma de poder que atua sobre todos os aspectos da vida humana, atingindo a todos e todas, seja nas relações com o trabalho, ou mesmo na vida como um todo? Esta, também parece ser uma questão para Negri (2001): 
O problema é compreender como a ação, o discurso, a resistência de um proletariado que, a partir de agora, se tornou intelectualidade de massa. Paradoxalmente, são os próprios trabalhadores que produzem as imagens, as linguagens e as formas utilizadas para construir a falsificação do mundo, para transformar o sentido da realidade, para subtrair a essa realidade toda significação antagonista. O problema principal se torna, então, a identificação, a partir das forças que vivem nesse tipo de mundo e que entraram nesse novo tipo de realidade, de uma forma de expressão material. Não uma forma de expressão alternativa - a alternativa implica sempre uma certa alusão ou uma analogia com o "velho" -, mas, ao contrário, uma expressão que consiga achar, dentro dessa unificação forçada, mundializada e comunicativa, pontos de apoio, pontos de ruptura, pontos suscetíveis de constituir o novo. (NEGRI, 2001, p.42)

Há que se reconhecer a existência de um sistema opressor que opera por forças maquínicas de produção contínua dos sujeitos, que por sua vez se rendem a práticas niveladoras de "jogos de verdade", ou seja, um conjunto de procedimentos e práticas pelas quais a verdade é instituída. Foucault (1983) define essas práticas como uma forma de racionalidade ou a uma certa regularidade que organiza o que os homens fazem e como devem conduzir suas vidas. Portanto, as questões aqui levantadas pela professora, que por sua vez foram suscitadas pelo filme e pelos argumentos marxistas da sua aluna, mesmo que aluna e professora se apoiem em referenciais teóricos diferentes, implicam em pensamentos sobre os modos de vida no mundo contemporâneo, sobre as formas de regulação de condutas que fixam modos reprodutores da vida, mas também, sobre a possibilidade de existências livres, que escapam desse controle, da capacidade de produção autônoma da vida.

Tudo isso leva a professora a pensar que a infância do filme, na figura de um menino, pode nos oferecer as pistas para forjarmos a emergência de criação de novas formas de resistência que se contraponham a esse poder assujeitador que se adensa e penetra em nossos cotidianos como tentáculos a nos sufocar.

Talvez caiba aqui um retorno ao diálogo com Negri (2001):

Hoje não há mais profeta capaz de falar do deserto e de contar o que sabe de um povo porvir, por construir. Só há militantes, ou seja, pessoas capazes de viver até o limite a miséria do mundo, de identificar as novas formas de exploração e sofrimento, e de organizar, a partir dessas formas, processos de libertação, precisamente porque têm participação ativa em tudo isso. [...] 
resta-nos apenas essa construção ontológica e constituinte 'direta', que cada um de nós deve vivenciar até o limite (...) Creio, portanto, que na época do pós-moderno e na medida que o trabalho material e o trabalho imaterial já não se opõem, a figura do profeta - ou seja, a do intelectual - está ultrapassada porque chegou a ser total acabamento; e é nesse momento que a militância se torna fundamental. Precisamos de pessoas como aqueles sindicalistas norte-americanos do começo do século, que pegavam um trem para o Oeste e que, a cada estação atravessada, paravam para fundar uma célula, uma célula de luta. Durante toda a viagem, eles conseguiam trocar suas lutas, seus desejos, suas utopias. Mas também precisamos ser como São Francisco de Assis, ou seja, realmente pobres: pobres, porque é somente nesse nível de solidão que podemos alcançar o paradigma da exploração hoje, que podemos captar-lhe a chave. Trata-se de um paradigma 'biopolítico', que atinge tanto o trabalho quanto a vida ou as relações entre as pessoas. Um grande recipiente cheio de fatos cognitivos e organizacionais, sociais, políticos e afetivos ... (NEGRI, 2001, p. 23-24).

Nosso menino nos fala um pouco dessa militância, da multiplicidade de bons encontros, do estreitamento de laços de afetos em tempos de redes esgarçadas em seus "nós", sejam eles, pronominais ou substantivos. Fala, também, da auto-organização de nossas próprias resistências; mapeando uma cartografia que se movimenta por encontros que potencializam a vida.

No encontro entre diferenças de pensamento entre a aluna e a professora, produziu-se outra diferença, que não trata de "figuras mediatizadas e referidas à representação, mas, ao contrário, estados livres ou selvagens da diferença em si mesma que são capazes de levar faculdades a seus limites respectivos. Não é a oposição qualitativa do sensível, mas um elemento que é em si mesmo diferença" (DELEUZE, 2006, p. 209) e que se encontraram na tentativa de criarem meios de construir inferências produtivas a partir de uma sinergia inesperada.

o que um menino nos deu a pensar?

(...) Menino, mundo, mundo, menino (...) Lembro da minha mão na sua mão E o "zói" enchem de água sem querer Menino, mundo, mundo, menino (...)

(Emicida) 
As escutas da aluna e da professora ora divergem, ora se fundem diante dos dilemas a serem enfrentados no tempo atual. Como diluir as fronteiras que aprofundam o abismo entre humanos? As cidades repartidas, a colonização do outro por um padrão narcísico de igualdade? Aceleração de um tempo vazio, que nos coloca na ponta da seta dos ponteiros dos relógios que delimitam o tempo em horas cronometradas e com isso nos rouba tempo para refletirmos sobre nossas questões existenciais.

Assim como "a mão do oleiro na argila do vaso", O menino e o mundo, nos pareceu desinteressado "em transmitir o 'puro em si' da coisa narrada como uma informação ou um relatório. Ele mergulha a coisa na vida do narrador para em seguida retirá-la dele, imprimindo na narrativa a marca do narrador" (BENJAMIN, 1985, p.205).

Assim, também, se cria uma espécie de política de tempo. Através de animações em 2D, de desenhos feitos com giz de cera, rabiscos, aquarelas e colagens, um trabalho artesanal que dá forma ao longa-metragem, colocando as imagens em movimento numa lentidão que nos possibilita, sob o olhar da infância, ver aquilo, que por falta de tempo, não nos permitimos enxergar com acuidade.

É preciso largar as velhas tradições e se deixar contagiar por um pensamento que se faz nas conexões, que se produz nos devires e nas intensidades. Estamos falando de uma aposta na imanência, um jogo que ao mesmo tempo é resistência e criação. Sendo assim, não podemos mais evitar uma tarefa inadiável: substituir a noção freudiana de um inconsciente representativo-simbólico por uma noção de inconsciente produtivo-real.(DELEUZE \& GUATARRI, 2010, p.95) ${ }^{6}$

Vale lembrar aqui o encontro do menino com seu próprio ser já crescido em dois momentos do filme, na fase adulta e na velhice, temporalidades distintas, mas que nos interroga sobre o que temos feito de nossas vidas.

O filme não trata apenas da visão de uma criança sobre a sociedade capitalista atual, uma sociedade cruel, exploradora, na qual tantos vivem com pouquíssimo e poucos vivem com tanto que nem dão conta de saber quanto. $\mathrm{O}$

\footnotetext{
${ }^{6} \mathrm{https}: / /$ razaoinadequada.com/filosofos-essenciais/deleuze/inconsciente-maquinico/
} 
filme é muito mais que essa denúncia. É a Arte em sua máxima potência libertadora. Um recado poético para a humanidade, um convite para olharmos o mundo com o olhar sensível da nossa infância tantas vezes adormecida em nós.

\section{referências}

Filme: O MENINO e o Mundo.

Direção: Alê Abreu.

Produtora: Filme de Papel - Brasil, 2013. 85 min. Som, Cor.

BENJAMIN, Walter. Obras escolhidas I: Magia e Técnica, Arte e Política. São Paulo: Brasiliense, 1985

CHAUÍ, Marilena. Janelas da Alma, Espelhos do Mundo. In: NOVAES, Adauto (org). O olhar. São Paulo: Cia das Letras, 1998.

DELEUZE, Gilles. Cinema I: A imagem-movimento. São Paulo, SP: Brasiliense, 1993

DELEUZE, Gilles. Conversações. SP: Editora 34, 1992

DELEUZE, Gilles. Crítica e clínica (P. Pál Pelbart, trad.). São Paulo, SP: Editora 34, 1997.

DELEUZE, Gilles. Proust e os signos. Rio de Janeiro: Forense Universitária, 2003.

DELEUZE, Gilles. Diferença e Repetição. $2^{\mathrm{a}}$ ed. Rio de Janeiro: Graal, 2006.

DELEUZE, Gilles \& GUATARRI, Felix. O Anti-Édipo: Capitalismo e Esquizofrenia. SP.:

Editora 34, 2010.

FOUCAULT, Michel. "A ética do cuidado de si como prática da liberdade". In: Ditos \& Escritos. V -Ética, Sexualidade, Política. Rio de Janeiro: Forense, 1983,

FRIGOTTO, Gaudêncio, CIAVATTA, Maria e RAMOS, Marise. O trabalho como princípio educativo no projeto de educação integral dos trabalhadores. In: COSTA, Hélio e CONCEIÇÃO, Martinho. Educação integral e sistema de reconhecimento e certificação educacional profissional. São Paulo: Secretaria Nacional de Formação - CUT, 2005.

MARTON, Silmara Lidia \& SILVA, Dagmar de Mello. Escutando crianças: o que elas nos deram a pensar? Childhood \& Philosophy, Rio de Janeiro, v. 10, n. 20, jul-dez. 2014, pp. 267282.

MARX, Karl. O capital, Livro Primeiro, volume I. São Paulo: Editora Nova Cultural Ltda., 1996.

MARX, Karl. Primeiro Manuscrito, in: Manuscritos Econômicos, 2017 Disponível em: <https://www.marxists.org/portugues/marx/1844/manuscritos/cap01.htm> Acesso em: 20/07/2017

NEGRI, Antônio. Exílio. Iluminuras, São Paulo: 2001.

PEIXOTO, Nelson Brissac. O olhar do estrangeiro. In: NOVAES, Adauto (org.). O olhar. São Paulo: Companhia das Letras, 1990.

RANIERI, Jesus. A câmara escura. Alienação e estranhamento em Marx. São Paulo: Bomtempo, 2001.

TRINDADE, Rafael. Nietzsche e a Comunicação (ou tornar-se comum). Razão Inadequada. IDisponível em: <https://razaoinadequada.com/2014/07/30/nietzsche-e-acomunicacao-ou-tornar-comum/comment-page-1/> Acesso em: 20/07/2017

UNIVERSIDADE FEDERAL FLUMINENSE. Faculdade de Educação. Projeto Pedagógico e Estrutura Curricular do Curso de Pedagogia - Formulário 05. UFF: FEUFF, $2010 \mathrm{~b}$. 